\title{
Commitment in WAQF Development through Cross-Sector Collaboration between Islamic Financial Institutions and State Islamic Religious Councils: Innovative Strategy of Value-Based Intermediation for Sustainability
}

\author{
Siti Sara Binti Ibrahim, ${ }^{1}$ Abd Halim Mohd Noor, ${ }^{2}$ Shafinar Ismail, ${ }^{3}$ Roshayani Arshad, ${ }^{4}$ \\ Mohd Ali Muhamad Don ${ }^{5}$ \\ ${ }^{1}$ Business Management Faculty, Universiti Teknoloogi MARA, Negeri Sembilan, Malaysia \\ ${ }^{2,3}$ Business Management Faculty, Universiti Teknoloogi MARA, Melaka, Malaysia \\ ${ }^{4}$ Accounting Research Institute, Universiti Teknoloogi MARA, Shah Alam, Malaysia \\ ${ }^{5}$ Academy of Contemporary Islamic Studies, Universiti Teknoloogi MARA, Johor, Malaysia
}

\begin{abstract}
Objective - Islamic Financial Institutions (IFIs) are founded upon principles of encouraging economic wellbeing for the betterment of society. Despite this, fresh measures are required to ascertain the sustainability of IFIs due to the deterioration recorded in annual rate growth levels that has slumped to $8.2 \%$ in 2016 , compared to $24.2 \%$ in 2011 . Similarly, waqf, which aims to contribute to socio-economic growth, appears to underperform due to inefficient management and lack of resources from State Islamic Religious Councils (SIRCs) in Malaysia. Therefore, growing attention is given to adding value to related operations so as to continuously expand without undermining their obligation towards societal welfare.

Methodology/Technique - In responding to this issue, Value-Based Intermediation (VBI) through a cross-sector collaboration strategy has been proposed in this paper to streamline the investments of IFIs in executing their business responsibilities in a strategic manner, especially to generate sustainable socio-economic growth through waqf development projects. Nonetheless, in order to strategically perform in project collaboration for sustainability, strong commitment from IFIs and SIRCs is needed.

Findings - A significantly positive relationship was discovered between the independent variables (affective commitment, normative commitment, and continuous commitment) and organisational sustainability.

Novelty - The paper concludes with an assumption of the readiness of both organisations in effectively developing waqf projects, along with several recommendations for future studies in further contributing to the success of waqf development which will contribute to organisational sustainability.
\end{abstract}

Type of Paper: Empirical.

JEL Classification: G20, G21, G29.

Keywords: Islamic Financial Institutions; State Islamic Religious Councils; Strategic Collaboration; Sustainability; Value Based Intermediation.

\footnotetext{
* Paper Info: Received: December 18, 2018

Accepted: March 16, 2019

Corresponding author: Siti Sara Binti Ibrahim

E-mail: sitisara2212@gmail.com

Affiliation: Business Management Faculty, Universiti Teknoloogi MARA, Negeri Sembilan, Malaysia
} 


\section{Introduction}

A growing number of major institutional funds and investors subscribing in assets based on sustainable and responsible objectives or principles have begun placing their focus on sustainable development goals so as to gain substantial momentum in the present marketplace (Arshad, Muda, Nair, \& Baharudin, 2018). Nevertheless, the sustainable impact upon socio-economic development is questionable as the statistics portrays a decrease in the growth rate amongst Islamic Financial Institutions (IFIs) with a drop to $8.2 \%$ in 2016, compared to 24.2\% in 2011 (Bank Negara Malaysia [BNM], 2018). Hence, the Islamic financial industry in Malaysia needs to realign its focus beyond compliance, towards more wholesome value creation and value-based activities in ascertaining the long-term sustainable growth of socio-economic development.

Within the context of waqf, the properties have attracted much focus from a wide range of sources upon discovering that the development potential generated by waqf properties is closely associated with socioeconomic growth. Unfortunately, a number of State Islamic Religious Councils (SIRCs) approach waqf from a conventional perspective that revolves solely around religious motivations. As such, a substantial amount of waqf land appears to be unused, without its value potential being harnessed for the betterment of the Muslim community. This fact puts SIRCs in a dilemma regarding how best to develop and manage waqf properties under their care. Statistics shows that a considerable amount of Malaysian waqf land has yet to be developed, while only $30 \%$ of land has been cultivated for various purposes, such as rental housing, shop lots, agriculture sites, and petrol stations (Shazrin, Azmi, Hanif, \& Mahamood, 2017). This scenario is a consequence of poor management and planning, as well as insufficient staffing and financing, among many other issues (Hassan, Aziani, \& Bostaman, n.d.).

Responding to this issue, this study examines the collaboration between IFIs and SIRCs within the context of Malaysia through waqf development projects for sustainable impact on socio economic development. In order to strategically perform in the project collaboration, strong commitment from IFIs and SIRCs is needed. Hence, this study empirically analyses the impact of independent variables (affective commitment, normative commitment, and continuous commitment) on corporate sustainability.

This study applies the cross-sector collaboration strategy adapted from Value-Based Intermediation (VBI), which was recently initiated in a strategy paper by the central bank. In addition, the VBI has been deemed as the most suitable strategy to address the problems faced by IFIs and SIRCs in contributing to socio-economic development and to their own organisational sustainability. It is crucial for this study to highlight the significance of commitment displayed by both domains so as to succeed in the collaboration projects, to deliver benefits to socio-economic development, and to achieve organisational sustainability. This study also responds to a recent collaborative project initiated by both sectors called "MyWakaf" which is parallel to the goal outlined in VBI for sustainability.

This paper is organised as follows. First, an overview of the basic literature is presented after describing the background of study in the introduction. Next, the study empirically assesses the commitment exerted by IFIs and SIRCs toward collaboration for sustainability. The Resource-Based View (RBV) theory was applied as it highlights commitment as an intangible resource that needs to be adhered to by an organisation to ensure successful collaboration, and to contribute to organisational sustainability.

\section{Literature Review - Additional Theory Used}

\subsection{Development of Islamic Financial Institutions in Malaysia}

The growing need of Muslims for a Shari'ah-compliant financial system seems to drive the growth of Islamic finance. Early Muslims were unfamiliar with banking operations, and the concept of a bank as a modern institution is rather new amongst Islamic societies (Hussain, Shahmoradi, \& Turk, 2015). In Malaysia, Islamic financial activities have continuously focused on compliance with Shari'ah to ensure the 
legitimacy of Islamic financial products and services. Upon gaining legitimacy, coupled with the support of comprehensive market infrastructure, a robust regulatory framework, and dynamic market participants, the market shares of Islamic banks in Malaysia rose from 7.1\% in 2010 to $28.0 \%$ in 2016. Nevertheless, the annual growth rate of Islamic banks had declined from 24.2\% in 2011 to $8.2 \%$ in 2016 (BNM, 2018). Such significant decline signals that the Islamic financial industry needs to realign its focus beyond compliance, towards more wholesome value creation and value-based activities in ensuring long-term sustainable growth.

\subsection{WAQF Development in Malaysia}

Waqf has been a historically prominent aspect amidst the Islamic society, ranging from the days of the Prophet Muhammad (p.b.u.h.) to the early $19^{\text {th }}$ century (Mohsin, 2013). In modern times, waqf and its impressive ability to facilitate socio-economic development has received much interest from the industry. Nonetheless, the role played by waqf in establishing the sustainable growth of financial resources and in addressing social disparity should be supported with strong development of waqf assets, as well as effective strategies and implementation.

In Malaysia, waqf property administration, management, and development lie within the jurisdiction of the SIRCs in each state. Therefore, SIRCs are responsible as mutawalli in waqf management in their respective state. Unfortunately, the growth of waqf in Malaysia is bound to remain deficient if the SIRCs continue to establish waqf on an individual basis. Therefore, collaboration from various sectors may indeed be the answer to the issues related to sustainable impact that further contributes to socio-economic development.

\subsection{Overview of Value-Based Intermediation for Cross-Sector Collaboration}

Cross-sector collaboration within the context of waqf has been considered as the ideal and strategic choice. The collaborative relationships between IFIs and SIRCs have become more widespread and appear to be vital for all parties involved. An amalgamation of social, economic, and political demands is the driving force behind these collaborations (Austin, 2000; Austin \& Austin, 2011). In line with the aim stipulated by the Malaysian government, socio-economic sustainability may be attained by promoting collaborative correlations between the social sector, private firms, and the government.

A similar notion has been put forth in a strategy paper entitled "Value-Based Intermediation (VBI): Strengthening the Roles and Impact of Islamic Finance" by the Central Bank of Malaysia in July 2017. This poses a reflection on reassessment of priorities carried out by IFIs in Malaysia in their attempt to focus on sustainability in local socio-economic growth and not merely on profit. Inclusion of waqf in this context suggests the adoption of these strategies (VBI) to achieve sustainability provided they can be implemented effectively across all Malaysian industries and sectors. As such, this strategy paper looks into reinforcing IFIs and SIRCs by adopting VBI as a common vision for the industry to create a collective effort in collaboration towards meeting common objectives in light of sustainable socio-economic development.

\subsection{Commitment as an Intangible Resources in the Resource-Based View Theory}

Resources in the RBV theory are the means through which firms accomplish their activities. In order to illustrate the RBV theory within resources for competitive advantage, the theory has indicated that the resources in RB rely on the classification as tangible or intangible resources (Branco \& Rodrigues, 2006; Julienti Abu Bakar \& Ahmad, 2010). Tangible resources (Barney, Wright, \& Ketchen, 2001b) refer to resources as physical or financial capital, including cost savings and improved efficiency due to partnership involvement. Intangible resources, on the other hand, include human capital, inclusive of gained knowledge due to engagement in partnership. 
Turning to this study, intangible resources, namely commitment, is considered as the primary resource due to its suitability for relationship resources and its function as a vital component in fruitful collaboration (Barney, Wright, \& Ketchen, 2001a; City, 1993; Okpara, 2015). Commitment refers to the acceptance of and strong belief in the goals and values of a project, the willingness to engage in a project, and the desire to maintain membership in a project (Cullen, Parboteeah, \& Hoegl, 2004). In projects, commitment is a key success factor for interpersonal and cross-sector collaboration (Miro \& Zaborek, 2018). In the context of this study, commitment is defined from an organisational perspective and is composed of three distinct forms: affective commitment, continuous commitment, and normative commitment.

\section{Research Methodology}

This study examines collaborative waqf project development, with a particular emphasis on the commitment displayed by IFIs and SIRCs in developing waqf assets in Malaysia. This study empirically assesses the availability of resources between IFIs and SIRCs to collaborate a waqf development project. The three selected aspect of commitment (affective commitment, normative commitment, and continuous commitment) were measured to determine their impact on corporate sustainability.

A set of questionnaires that measure commitment and organisational sustainability were disseminated to 16 IFIs and 14 SIRCs in Malaysia based on the list obtained from the Central Bank of Malaysia. A total of 30 respondents from IFIs and SIRCs in Malaysia were gathered as the unit of analysis for this study to measure their level of commitment in project collaboration towards achieving corporate sustainability. This study looks at resources to leverage success of the collaboration for sustainable socio-economic development in light of the RBV theory. Diagram 1 illustrates the variables embedded in the proposed conceptual framework for the study.

\section{Diagram 1: Conceptual Framework of Study}

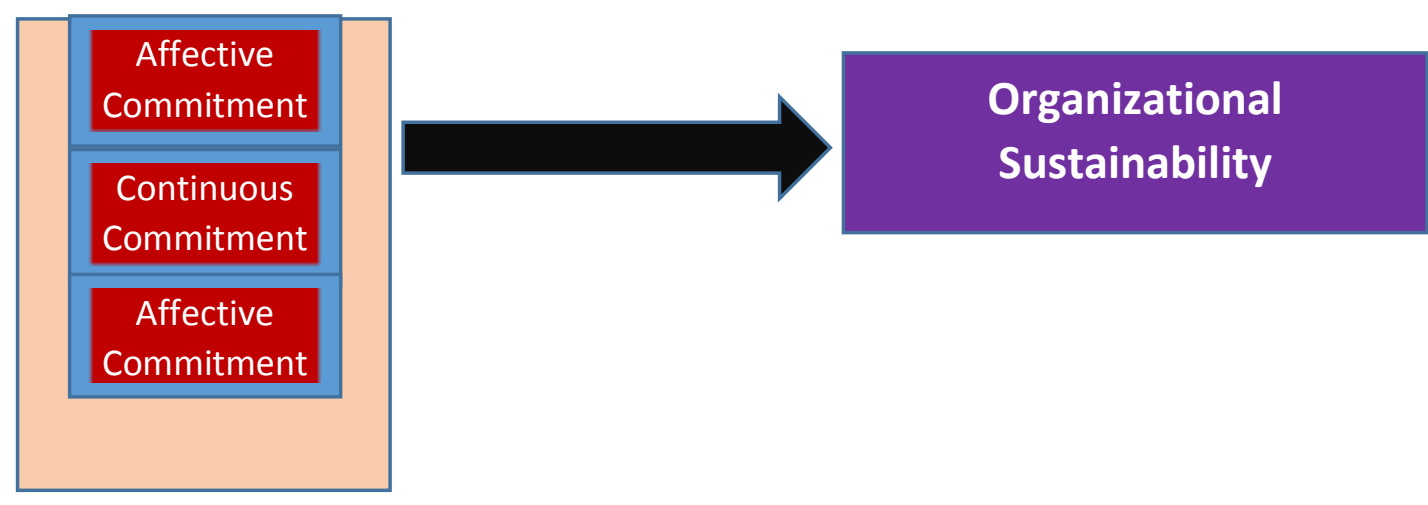

\section{Results - Redrawing the Results Table}

\subsection{Commitment Toward Project Collaboration Using a Regression Model}

Table 1. Model Summary

\begin{tabular}{c|c|c|c}
\hline Model & R & $\begin{array}{c}\text { Adjusted R } \\
\text { Square }\end{array}$ & $\begin{array}{c}\text { Standard Error of } \\
\text { the Estimate }\end{array}$ \\
\hline Commitment & 0.697 & 0.427 & 0.54813 \\
\hline
\end{tabular}


Table 1 presents the regression model of affective commitment, continuous commitment, and normative commitment, wherein their function as predictors explains only $42.7 \%$ of the variation in corporate sustainability. The other predictor variables are explained by the remaining $57.3 \%$.

Table 2. ANOVA

\begin{tabular}{c|c|c|c|c|c}
\hline Model & F & $\begin{array}{c}\text { Significant } \\
\text { Value }\end{array}$ & $\begin{array}{c}\text { Sum of } \\
\text { Squares }\end{array}$ & $\begin{array}{c}\text { Mean } \\
\text { Square }\end{array}$ \\
\hline Commitment & Regression & 8.211 & .001 & 7.401 & 2.467 \\
\hline & Residual & & & 7.812 & .300 \\
\hline & Total & & & 15.213 & \\
\hline
\end{tabular}

Table 2 displays the outcomes retrieved from ANOVA, whereby the regression model has been considered fit and can be further used for prediction $(\mathrm{F}=8.211$, $\mathrm{p}$ value $=0.002<0.05)$.

Table 3 shows that all the tolerance values exceed 0.10 and the VIF values are below 10, which signify nil multicollinearity issue. Among the four independent variables embedded into the model, only one independent variable (affective commitment, $\mathrm{t}=3.181, \mathrm{p}$-value $=0.004,<0.05$ ) exhibited statistically significant contributions towards corporate sustainability. Hence, insignificant variables were discarded to improve the model.

Table 3. Coefficients

\begin{tabular}{c|c|c|c|c|c|c|c|c}
\hline Model & & \multicolumn{2}{|c|}{$\begin{array}{c}\text { Unstandardized } \\
\text { Coefficients }\end{array}$} & $\begin{array}{c}\text { Standar } \\
\text { dized } \\
\text { Coefficie } \\
\text { nts }\end{array}$ & t & & Sig. & \multicolumn{2}{c}{$\begin{array}{c}\text { Collinearity } \\
\text { Statistics }\end{array}$} \\
\hline & & B & $\begin{array}{c}\text { Std. } \\
\text { Error }\end{array}$ & Beta & & & Tolerance & VIF \\
& Constant & .114 & 1.357 & & .084 & .934 & & \\
\hline Commitment & AC & .491 & .154 & .547 & 3.181 & .004 & .669 & 1.495 \\
\hline & $\mathrm{CC}$ & .085 & .179 & .080 & .474 & .640 & .690 & 1.450 \\
\hline & $\mathrm{NC}$ & .350 & .224 & .230 & 1.561 & .131 & .911 & 1.098 \\
\hline
\end{tabular}

Based on Table 3, all the independent variables exhibited positive correlations with the dependent variable (corporate sustainability). The Standardised Beta Coefficients signify the crucial independent variables to the model by determining the largest value and neglecting other negative signs. As given in the coefficients table, affective commitment (Beta $=0.547$ ) makes the largest contribution to the model.

\section{Regression model: $\gamma=\beta 0+\beta 1 \rho 1+\beta 2 \rho 2+\beta 3 \rho 3$}

$$
\gamma=0.114+0.492 \rho 1+0.85 \rho 2+0.35 \rho 3
$$

\section{Discussion and Recommendations}

A substantial number of academic studies have raised concerns pertaining to the development of waqf properties with the objective of transforming this institution into one that is independent and sustainable in 
generating consistent benefits to the community. With that, numerous ideas and proposals have been tabled to improve the present scenario by looking at both the fundamental and operational aspects of waqf. These brilliant ideas are valuable, but it takes time for the responsible authorities to address, recognise, approve, and implement these ideas until they have been assessed.

The outcomes of this study reveal that commitment has a significantly positive correlation with organisational sustainability in light of waqf project development through cross-sector collaboration between IFIs and SIRCs in Malaysia. Affective commitment offers the largest contribution to the model. Therefore, both sectors must reassess this variable prior to start of a project. This study concludes that upon establishing commitment between the members in any collaborative project, or specifically in the context of waqf-based projects, other intangible and tangible resources may assist in the success of the performance exerted by project collaboration that eventually leads to organisational sustainability.

In addressing the study limitations, more samples are recommended to empirically verify the capabilities of firms in dedicating their resources for successful implementation of project collaborations and continuous sustainability for socio-economic wellbeing. In addition, this study recommends the incorporation of another independent variable to assess project collaboration, particularly waqf development projects, between IFIs and SIRCs.

\section{Conclusions, Implications and Significance of the Study}

Collaboration between IFIs and SIRCs in Malaysia seems to provide a significantly positive contribution to the development of waqf and the subsequent growth of socio-economic wellbeing. Such cross-sector partnerships are bound to assist in addressing issues related to under-utilised waqf land assets, aside from being relevant to realising or revising the wishes of the founder. Nevertheless, resource management has been reported as a pressing issue that must be foregrounded by the SIRCs and their partners in order to ensure that the performance of a project collaboration can contribute to sustainable socio-economic growth. In fact, reviews of the literature have revealed several gaps pertaining to the impact of intangible resources in terms of cross-sector collaboration on the development of waqf assets.

In an attempt to bridge these gaps, the present study formulates a research framework based on the RBV theory to identify the aspects of commitment as potential resources to IFIs and SIRCs in light of waqf development projects through cross-sector collaboration practices. Additionally, this study recommends that future research may tap into a larger sample to increase the significance of the findings, since this study has a particular limitation in obtaining a sufficient number of respondents, primarily because this subject matter is still in its infancy among academia as well as in the industry itself.

\section{Acknowledgements}

This paper is funded by FRGS grant code; 600-IRMI/FRGS 5/3 (37/2016), between UiTM and the Ministry of Higher Education (MOHE).

\section{References}

Arshad, R., Muda, R., Nair, R. and Baharudin, I. (2018). Value-based Intermediation for Islamic Banking Institutions Directed Towards Sustainable Development Goals, 1(1), 1-17.

Austin, J. E. (2000). Strategic Collaboration Between Nonprofits and Businesses. Nonprofit and Voluntary Sector Quarterly, 29(1), 69-97. https://doi.org/10.1177/089976400773746346.

Austin, J. E. and Austin, J. E. (2011). From Organization to Organization: On Creating Value, (2010), $13-14$. https://doi.org/10.1007/s10551-011-0787-z.

Barney, J., Wright, M. and Ketchen, D. J. (2001a). Journal of Management. https://doi.org/10.1177/014920630102700601. 
Barney, J., Wright, M. and Ketchen, D. J. (2001b). The Resource-based View of the Firm: Ten Years After 1991. Journal of Management, 27(6), 625-641. https://doi.org/10.1016/S0149-2063(01)00114-3.

BNM. (2018). Value-Based Intermediation: Strengthening the Roles and Impact of Islamic Finance, (March).

Branco, M. C. and Rodrigues, L. L. (2006). Corporate Social Responsibility and Resource-based Perspectives. Journal of Business Ethics, 69(2), 111-132. https://doi.org/10.1007/s10551-006-9071-z.

City, D. (1993). A Framework Linking Intangmke Resources and Capabilities to Sustainable Competitiveness, (July 1992), 14.

Cullen, J. B., Parboteeah, K. P. and Hoegl, M. (2004). Cross-National Differences in Managers' Willingness to Justify Ethically Suspect Behaviors: A Test of Institutional Anomie Theory Author(s): John B. Cullen, K. Praveen Parboteeah and Martin Hoegl. Cross-national Differences in Managers' Willingness. Academy of Management Journal, 47(3), 411421.

Hassan, R., Aziani, N. and Bostaman, M. (n.d.). Wawf Development in Majlis Agame Islam Wilayah Persekutuan, 5, $1-7$.

Hussain, M., Shahmoradi, A. and Turk, R. (2015). An Overview of Islamic Finance. IMF Working Papers, 15(120), 1. https://doi.org/10.5089/9781513590745.001.

Julienti Abu Bakar, L. and Ahmad, H. (2010). Assessing the Relationship Between Firm Resources and Product Innovation Performance. Business Process Management Journal, 16(3), 420-435. https://doi.org/10.1108/14637151011049430.

Miro, D. and Zaborek, P. (2018). NGO - Business Collaboration: A Comparison of Organizational, Social and Reputation Value From the NGO Perspective in Poland, 1-20. https://doi.org/10.1177/0899764018797476.

Mohsin, M. I. A. (2013). Financing Through Cash-waqf: A Revitalization to Finance Different Needs. International Journal of Islamic and Middle Eastern Finance and Management, 6(4), 304-321. https://doi.org/10.1108/IMEFM-082013-0094.

Okpara, J. O. (2015). Exploring the Effects of Intangible Resources on Competitive Advantage and Performance of Listed Firms in Nigeria. (2012). Business and Applied Sciences Academy of North America, 8.

Shazrin, A., Azmi, M., Hanif, N. R. and Mahamood, S. M. (2017). Exploring the Social Reality of Waqf Community Using Social Media: The Netnography Approach. 